\title{
ZSIGMOND CSABA
}

\section{A rendőrségi fegyverhasználat}

A rendőrségi fegyverhasználatot a rendszerváltozás után a rendőrségről szóló, ma is hatályos 1994. évi XXXIV. törvény szabályozza. Jelentős változást a 9/2004. (III. 30.) AB határozat hozott, amely egyebek között alkotmányellenesnek minősítette a törvény 54 . $§$ h) pontját, amely az állam elleni, illetve emberiesség elleni büncselekmények elkövetőjének elfogása és szökésének megakadályozása esetén tette lehetővé a fegyverhasználatot.

Kiemelendő a 62/2007. (XII. 23.) IRM rendelet által bevezetett gyakorlati változás, amely a szolgálati elöljáró kötelességévé tette a lőfegyverhasználat jog- és szakszerüségének kivizsgálását, ellentétben a korábbi 3/1995. (III. 1.) BM rendelet elöírásaival, amely szerint minden esetben az ügyészség feladata volt a fegyverhasználat kivizsgálása. A jelenleg hatályos szolgálati szabályzat is a szolgálati elöljáró feladatává teszi a kivizsgálást.

\section{A rendőri fegyverhasználat fogalma, alapelvei, alanya}

Az Rtv. 53. § (1) bekezdése szerint: „Löfegyverhasználatnak csak a szándékosan, személyre leadott lövés minösül."

A lőfegyverhasználatnál megkívánt szándékosságot az Rtv. nem fejti ki. Nagy-Juhák István fegyverhasználatról szóló jegyzete szerint: „,Szándékosnak az itélöképessége birtokában lévö rendör tudatos és akaratlagos cselekvését kell érteni."

Az idézett fogalmi meghatározás szerint ahhoz, hogy egy rendőr által leadott lövést lőfegyverhasználatként értékeljünk, a lövésnek négy fogalmi elemnek kell megfelelnie:

- a rendőrnek a lövés leadásakor az itélőképessége birtokában kell lennie;

- a lövésnek tudatosnak kell lennie;

- a lövésnek akaratlagosnak kell lennie;

- a lövésnek más személy ellen kell irányulnia.

1 Nagy-Juhák István: A rendőr fegyverhasználati joga. BM Kiadó, Budapest, 1997, 5. o. 
Az itélőképesség fogalmi megértéséhez a büntetőjog-irodalomban ismert beszámítási képesség fogalmat tekinthetjük alapnak. Nagy Ferenc szerint a beszámítási képességet kizárja a kóros elmeállapot, kényszer, fenyegetés, illetve az önhibából eredő ittas és bódult állapot. ${ }^{2}$ Gyakorlati értelemben nem értékelhető fegyverhasználatként az olyan rendőr által leadott lövés, aki a lövés leadásakor nem volt beszámítható állapotban (kóros elmeállapotban, kényszer, fenyegetés hatása alatt, illetve ittas vagy bódult állapotban adta le a lövést). A rendőr által ilyen állapotban leadott lövés nem vizsgálható az Rtv. alapján fegyverhasználatként, hiába áll fenn esetlegesen a lőfegyverhasználat valamely, az Rtv.-ben felsorolt különös feltétele. A lövés pontos körülményeinek vizsgálata csak büntetőeljárás keretein belül lehetséges, ezért az illetékes nyomozó ügyészségnél büntetőeljárást kell kezdeményezni.

A lövés tudatossága a lövés leadásakor a rendőri fegyverhasználat releváns tényének helyes felismerését, ismeretét jelenti. A rendőri fegyverhasználat során a lövést leadó rendőr tudatának át kell fognia, hogy a fegyverhasználat Rtv.-ben felsorolt valamely esete áll fenn, tehát például jogos védelmi helyzetben van, élet elleni közvetlen támadást kell elháritani, valaki löfegyverrel, robbanóanyaggal akar büncselekményt elkövetni, stb.

A törvényben felsorolt esetek összes releváns körülményét ismernie kell: a támadás valóban élet ellen irányult, a használt eszköz valóban lőfegyver vagy robbanóanyag volt stb., ezekkel a tényekkel kapcsolatban nem állhat fenn téves tudattartalom.

A lövés akaratlagossága a rendőr aktív, a lövésre irányuló, szándékos magatartását jelenti. A rendőr az említett ítélőképessége birtokában, a lőfegyverhasználat feltételeit alkotó tények helyes tudatában, szándékosan ad le lövést. A szándékos magatartás a büntetőjog-irodalom szerinti szándékosság (azon belül is az egyenes szándék) akarati-érzelmi oldalát jelenti. Az intézkedő rendőr a releváns tények ismeretében akarja, hogy a lőfegyverből kilépő lövedék az intézkedés alatt álló személy testét találja el.

\section{A rendőri fegyverhasználat alapelvei}

Mind az intézkedő rendőr, mind a kivizsgáló parancsok számára adódhatnak olyan szituációk, amelyek során nehéz megítélni a hatályos szabályozás alapján a kényszerítő eszköz jogszerüségét, azonban konkrét szituációkban a

2 Nagy Ferenc: A magyar büntetőjog általános része. Korona Kiadó, Budapest, 2001, 219. o. 
fegyverhasználat elemzésénél az alapelvek segítségével könnyebb értelmezni a törvényt. Az alapelvek - tekintve a joghézagokat és az eltérő értelmezési lehetőségeket - ezért egyes jogesetek megítéléséhez segítséget adhatnak.

Az alapelveket az alaptörvény, az Rtv., a szolgálati szabályzat, és az Alkotmánybíróság fegyverhasználattal kapcsolatos alkotmányossági megállapításai alapján lehet lefektetni.

Hivatkozott jegyzetében Nagy-Juhák István a következő alapelveket fektette le a rendőri fegyverhasználattal kapcsolatban:

a) törvényhez kötöttség elve;

b) arányosság elve;

c) humanitás elve;

d) a jog és kötelezettség egységének elve;

e) a ,végsö eszköz" elve.

Ezek az 1997-ben kidolgozott alapelvek a mostani jogi környezetben (új alaptörvény, új szolgálati szabályzat) is megállják a helyüket, így az alkalmazásuk segíthet jogalkalmazói gyakorlatban.

\section{A törvényhez kötöttség elve}

Az alaptörvény a Szabadság és felelösség címü fejezetben megfogalmazza az alapvető emberi jogokat, így egybek között az élethez, személyi szabadsághoz, emberi méltósághoz való jogokat, amelyek mindenkit egyformán illetnek meg. Ezektől senkit nem lehet önkényesen megfosztani. ${ }^{3}$ A rendőri fegyverhasználat azonban korlátozhatja a felsorolt alapjogokat, elsősorban az élethez való jogot, így a törvényhez kötöttség alapelve azt jelenti, hogy csak a rendőrségi törvényben meghatározott esetekben és módon van lehetőség a fegyverhasználatra, amely alapvető emberi jogokat korlátozhat.

Az arányosság elve

Ez az alapelv az Rtv. 15. §-ában megfogalmazott arányossági követelményből vezethetö le.

E szerint: „,15. § (1) A rendőri intézkedés nem okozhat olyan hátrányt, amely nyilvánvalóan nem áll arányban az intézkedés törvényes céljával.

3 Alaptörvény II. cikk: „Az emberi méltóság sérthetetlen. Minden embernek vele született joga van az élethez és az emberi méltósághoz, a magzat életét a fogantatástól kezdve védelem illeti meg." 
(2) Több lehetséges és alkalmas rendöri intézkedés, illetöleg kényszeritö eszköz közül azt kell választani, amely az eredményesség biztositása mellett az intézkedéssel érintettre a legkisebb korlátozással, sérüléssel vagy károkozással jár."

A szolgálati szabályzat szerint „,39. § (1) Az Rtv. szerinti kényszeritő eszköz csak akkor alkalmazható, ha az intézkedés alá vont magatartása, ellenszegülésének mértéke annak Rtv. szerinti alkalmazását indokolja. A nagyobb korlátozással, sérüléssel vagy károkozással járó kényszeritö eszköz akkor alkalmazható, ha a kisebb korlátozással, sérüléssel vagy károkozással járó kényszerítö eszköz alkalmazása nem vezetett eredményre vagy sikere eleve kilátástalan."

Az alapelv a jogos védelem arányosság (szükségesség) fogalmával azonos. A jogos védelem esetén az arányosság (szükségesség) azt jelenti, ha rendelkezésre áll enyhébb elhárítási mód, amellyel egyértelmủen és biztonságosan elhárítható egy támadás, elvárható, hogy a védekező azzal hárítsa el. Ugyanez igaz a fegyverhasználatra is: ha enyhébb sérelmet okozó kényszerítő eszközzel elérhető az intézkedés célja, azt kell választani.

\section{A humanitás elve}

Ennek az alapelvnek lehetne az élet védelmének alapelve is a neve, mivel jegyzetében Nagy-Juhák az élethez, az emberi méltósághoz való jog alkotmányos alapjogából és azzal kapcsolatos alkotmánybírósági döntésekből vezeti le.

Az Rtv. különböző helyeken különösen fontos szabályokat fogalmaz meg ennek kapcsán: ,,2. § (1) A rendörség védelmet nyújt az életet, a testi épséget, a vagyonbiztonságot közvetlenül fenyegetö vagy sértö cselekménnyel szemben, felvilágositást és segitséget ad a rászorulónak. A rendörség tiszteletben tartja és védelmezi az emberi méltóságot, óvja az ember jogait.

16. § (4) A rendör nem alkalmazhat kínzást, kényszervallatást, kegyetlen, embertelen vagy megalázó bánásmódot, az erre vonatkozó utasitást köteles megtagadni. A rendör az ilyen magatartás tanúsitójával szemben, annak megakadályozása érdekében, a szolgálati beosztására, a rendfokozatára, személyére tekintet nélkül köteles intézkedni.

17. § (2) A rendöri intézkedés során a kényszeritö eszköz alkalmazása esetén lehetőleg kerülni kell a sérülés okozását, az emberi élet kioltását. Az intézkedés folytán megsérült személy részére - amint ez lehetséges - segitséget kell nyújtani, szükség esetén a rendör gondoskodik arról, hogy a sérülttet or- 
vos elláthassa, kórházi elhelyezése esetén a hozzátartozó vagy más, a sérülttel kapcsolatban álló személy erröl értesüljön."

Ezeket a szabályokat minden fegyverhasználatkor, és annak kivizsgálása során figyelembe kell venni, ezt az alapelvet ezek a szabályok töltik ki tartalommal.

A jog és kötelezettség egységének elve

A hivatkozott jegyzet a korábban hatályos rendőrség szolgálati szabályzatról szóló 3/1990. (III. 30.) BM rendeletben foglaltak alapján vezette le ezt az alapelvet, amely megfogalmazta: „, a rendör jogszerü szolgálata teljesitésekor köteles intézkedéseinek érvényt szerezni, ennek érdekében elözetes figyelmeztetést után joga van kényszeritö eszközök alkalmazására”.

Ennek kapcsán a jegyzet kifejtette: „Amennyiben a rendör csak löfegyver alkalmazásával tud intézkedésének érvényt szerezni - és erre az Rtv. alapján joga van - akkor a fentiek értelmében egyúttal kötelezett is a fegyverhasználatra."

Az alaptörvény 46. cikk (1) bekezdése szerint a rendőrség alapvető feladata a büncselekmények megakadályozása, felderítése, a közbiztonság, a közrend és az államhatár rendjének védelme.

Az Rtv. az intézkedési kötelezettség kapcsán kifejti

13. § (1) A rendör jogkörében eljárva köteles intézkedni vagy intézkedést kezdeményezni, ha a közbiztonságot, a közrendet vagy az államhatár rendjét sértö vagy veszélyeztetö tényt, körülményt vagy cselekményt észlel, illetve ilyet a tudomására hoznak. Ez a kötelezettség a rendört halaszthatatlan esetben szolgálaton kivül is terheli, feltéve, hogy az intézkedés szükségességének idöpontjában intézkedésre alkalmas állapotban van.

Mind az alaptörvény, mind az Rtv. rendelkezéséből kitünik, hogy a rendőr köteles bűncselekmények, közbiztonságot veszélyeztető cselekmények stb. észlelése esetén intézkedni. Ezek olyan konfliktushelyzetek lehetnek, amelyek megoldása rendőri fegyverhasználatot tehet szükségessé, így kötelezettséggé is válik a legsúlyosabb kényszerítő eszköz alkalmazása.

4 Nagy-Juhák István. i. m. 11. o. 
Az alapelv majdnem teljesen megegyezik a már említett arányosság (szükségesség) alapelvével. Az arányosság (szükségesség) alapelve ugyanezt követeli: akár élet elleni támadás elhárításánál sincs szükség fegyverhasználatra, ha a támadás testi kényszerrel is biztonságosan elhárítható. A jogalkalmazónak ezen alapelv kapcsán nemcsak azt kell vizsgálnia, hogy enyhébb kényszerítő eszköz is rendelkezésre állt volna-e, hanem azt is, hogy a fegyverhasználatot megelöző protokoll érvényesült-e, vagy ha mellőzték, arra törvényes lehetőség volt-e.

\section{A rendőri fegyverhasználat jog- és szakszerüsége}

Rendőri fegyverhasználat utáni kivizsgálás esetén elsődlegesen a jogszerüséget kell tanulmányozni. Az Rtv. figyelembevételével kiemelten vizsgálandó:

- a leadott lövésre az Rtv. 52. (jogos védelem, végszükség) vagy 55. §-ában felsorolt pontok valamelyike alapján került-e sor;

- az Rtv. 55. §-ban foglalt korlátozások érvényesülése: vétlen személy veszélyeztetése fennállt-e, vagy vétlen személy a lövéssel okozati összefüggésben megsérült, volt-e lehetőség állatra, tárgyra leadható lövésre ember helyett;

- az Rtv. 56. §-ában foglalt megelőző intézkedésekre sor került-e, ha nem, azok az Rtv. 56. § (2) bekezdése alapján voltak-e mellőzhetők.

A szolgálati szabályzat alapján jogszerúségi szempontból elsősorban a 47. §ban foglaltak érvényesülését kell vizsgálni.

47. § (1) A löfegyverhasználat során a lövést lehetöleg végtagra kell irányitani.

(2) Az Rtv. 55. §-ában meghatározottakon túl nincs helye a löfegyverhasználatnak, ha a löfegyverhasználat az államhatáron átlövést idézne elö, valamint a határúton közlekedö személlyel szemben, kivéve, ha fegyveresen vagy felfegyverkezve elkövetett támadást, vagy fegyveres ellenállást kell leküzdeni.

(3) Ha a törvény csak a közvetlen fenyegetés vagy támadás elháritása céljából teszi lehetővé a fegyverhasználatot és a közvetlen fenyegetés vagy támadás bármely oknál fogva megszünt, a löfegyverhasználati jogosultság is azonnal megszünik. A löfegyverhasználat további alkalmazásának helye nincs, ha az a célját elérte.

Ha a fegyverhasználat jogszerütlen, a fegyverhasználat büncselekménynek, vagy fegyelmi vétségnek minősíthető. 


\section{A rendőri fegyverhasználat szakszerúsége}

Minden rendőri fegyverhasználat után vizsgálandó a szakszerüség is. A szakszerüség nehezen definiálható fogalom, és a hatályos Rtv. sem fogalmazza meg jelentését. Buzás Gábor meghatározása szerint „, a szakszerüség az elöirásokban, ajánlásokban rögzitett, a gyakorlati tapasztalatok alapján kidolgozott és bevált taktikák és technikák hatékony, biztonságos alkalmazást jelenti"'s.

A rendőri fegyverhasználat szakszerüségi szempontból való vizsgálatakor a rendőri fegyverhasználattal kapcsolatban kialakított gyakorlati ajánlások érvényesülését kell elsősorban vizsgálni, amelyek elsősorban különböző intézkedéstaktikai szakkönyvekben találhatók.

Megjegyzem, nemcsak intézkedéstaktikai szakirodalomban találhatók ilyen típusú ajánlások, hanem a szolgálati szabályzat 5. § (4) bekezdése is tartalmaz effélét: „, A rendöri intézkedés során úgy kell eljárni, hogy a rendör megelözze megtámadását, lefegyverzését, továbbá akadályozza meg, hogy a figyelmét a szolgálati tevékenységtöl elvonják vagy lekötöttségét jogellenes cselekmény elkövetésére használják fel."

A szakszerütlen fegyverhasználat fegyelmi felelösséget is megalapozhat.

\section{A fegyverhasználat korlátai}

Az Rtv. 55. §-a korlátokat fogalmaz meg a rendőri fegyverhasználattal kapcsolatban.

55. § Nincs helye löfegyverhasználatnak - a fegyveresen vagy felfegyverkezve elkövetett támadás, fegyveres ellenállás leküzdése, illetőleg a tömegben lévö személlyel szembeni használat (57. §) kivételével - ha

a) olyan személy életét vagy testi épségét veszélyezteti, akivel szemben a löfegyverhasználat feltételei nem állnak fenn;

b) a rendöri intézkedés célja tárgyra vagy állatra leadott lövéssel is elérhetö.

Egy rendőri fegyverhasználatot is megalapozó helyzetben nehéz megítélni, hogy éppen veszélyeztetve van-e vétlen személy élete, testi épsége. Ilyen típusú helyzetben nem lehet kiszámolni a lövedékek útját. Ugyanígy nehéz helyzetbe kerül a kivizsgálást végző parancsnok is, ha vétlen személyt találat

5 Buzás Gábor: Közigazgatás - rendészet - rendőri intézkedés. PhD-értekezés. Pécsi Tudományegyetem Állam- és Jogtudományi Kar Doktori Iskola, Pécs, 2010 
ér, esetleg a vétlen személy meghal, míg az, akivel szemben fennállt a fegyverhasználat jogossága, csak könnyebben sérül.

A vétlen személyt ért lövés - ahogyan kifejtettem - nem minősül lőfegyverhasználatnak a hiányzó szándékosság miatt a vétlen személy tekintetében. Az ilyen eseteket vétlen lövésként kell vizsgálni. ${ }^{6}$

A törvény feloldja a korlátozást, ha fegyveresen, felfegyverkezve, fegyveresen elkövetett támadás, vagy így tanúsított ellenállás leküzdése, vagy a tömegben lévő személlyel szemben kerül sor fegyverhasználatra. Gyakorlatilag ilyen helyzetekben a rendőr - tekintet nélkül arra, hogy vétlen személyek megsérülhetnek - használhatja fegyverét az Rtv. által adott felhatalmazás alapján.

A törvény csak a felsorolt eszközökkel (fegyver, felfegyverkezve stb.) elkövetett támadások elhárítása esetén ad lehetőséget a fegyver használatra, ha vétlen személy élete, testi épsége veszélybe kerül. Érdekesség, hogy például nem biztosított a fegyverhasználat, ha vétlen személy élete veszélyeztetve van, és a támadás eszköz nélkül zajlik. Például olyan esetben, ha valaki puszta kézzel fojtogatja áldozatát, a rendőr nem lőhet a támadóra, ha a löirányban vétlen személy tartózkodik. Lőhet viszont olyan helyzetben, ha valakit fegyveres emberrabló tart fogva, aki pajzsként maga előtt tartja áldozatát. Ilyen esetben felhatalmazza a törvény arra, hogy „kilője” a túsz mögül az elkövetőt.

A b) pont kapcsán gyakorlati szempontból olyan helyzetekre kell gondolni, amikor valaki állattal (jellemzően kutyával) hajt végre támadást, itt a törvény elöírása alapján az állatra kell lőni. Tárgy esetében tipikus helyzet a jármüvel támadó személy, ez esetben a törvény elsősorban a jármüre irányuló lövést írja elö.

\footnotetext{
6 A vétlen lövés foglalkozás körében elkövetett gondatlan veszélyeztetésnek minősülhet, így a kivizsgáló parancsnoknak e gondatlan bűncselekmény tényállási elemeinek irányából kell vizsgálódnia. 165. § (1) Aki foglalkozási szabály megszegésével más vagy mások életét, testi épségét vagy egészségét gondatlanságból közvetlen veszélynek teszi ki, vagy testi sértést okoz, vétség miatt egy évig terjedő szabadságvesztéssel büntetendő. A cselekmény elkövetési magatartása a foglalkozási szabály megszegése. Foglalkozási szabályként a rendörségi törvény 55. §-ában foglalt elöírást kell tekinteni, vagyis vizsgálni kell, hogy a lövés leadásakor közvetlen veszélyben volt-e olyan személy élete, testi épsége, akivel szemben nem állt fenn a fegyverhasználat feltétele. A közvetlen veszély tekintetében vizsgálandó, hogy térben és időben konkrét személy vagy személyek vonatkozásában fennállhatott-e a sérülés reális esélye. Gyakorlatban például reális esély lehet erre akkor, ha a lövés irányában vétlen személyek tartózkodnak.
} 


\section{A fegyverhasználatot megelooző intézkedések}

56. § (1) A löfegyverhasználatot a következö sorrendben meg kell elöznie

a) felhivásnak, hogy a felhívott a rendöri intézkedésnek engedelmeskedjék;

b) más kényszeritö eszköz alkalmazásának;

c) figyelmeztetésnek, hogy löfegyverhasználat következik;

d) figyelmeztetö lövésnek.

(2) A löfegyverhasználatot megelözö intézkedések részben vagy teljesen mellözhetök, ha az eset összes körülményei folytán a megelözö intézkedésekre már nincs idö, és a késedelem az intézkedés eredményességét, a rendör vagy más személy életét, testi épségét közvetlenül veszélyezteti.

A törvény által elöírt megelőző intézkedések azt a célt szolgálják, hogy alkalmazásukkal a fegyverhasználat megelőzhető legyen, összhangban a végső eszköz elvével.

A b) pont kapcsán a törvény nem határozza meg a rendőrnek, hogy melyik kényszerítő eszközt alkalmazza, így ez a rendőr belátására van bízva. Azt kell alkalmaznia, amellyel szerinte elérhető az intézkedés célja.

A törvény fö szabályként fokozatosságot vár el, vagyis a felsoroltak szerint kell haladni olyan helyzetben, ha erre a körülmények lehetőséget adnak.

A (2) bekezdés szerinti kivétel lehetőséget ad a fokozatosság részben vagy egészben való mellözésére.

Részben való mellőzés lehetősége esetén az $a$ )-d) pontokban felsoroltak átugorhatók, felcserélhetők. Teljes mellőzés esetén a rendőr azonnal használhatja a fegyverét.

A törvény idő hiányában engedi meg a megelőző intézkedések részben vagy egészben való mellőzését, ha az arra fordított idő

- az intézkedés eredményességét;

- a rendőr vagy más személy életét, testi épségét közvetlenül veszélyezteti.

Az intézkedés eredményességének veszélyeztetése úgy értelmezendő, hogy az Rtv. 54. §-a alapján fennáll a fegyverhasználati jog, csupán fegyverhasználattal akadályozható meg egy abban foglalt cselekmény végrehajtása, és idő hiányában az Rtv. által előírt megelőző intézkedések mellőzhetők. Például közveszélyokozás elkövetőjével szemben kell alkalmazni, akinek a cselekménye csak azonnali lőfegyverhasználattal akadályozható meg, vagy büncselekmény lőfegyverrel való elkövetését kell megakadályozni stb. 
Jogalkalmazói gyakorlati kérdés, hogy a későbbiekben tárgyalt szituációs jogos védelem esetén hogyan értelmezhető ez a fokozatosság.

\section{A rendőri fegyverhasználat jogos védelem és végszükség esetén}

A konkrét szituációkat, amelyekben a rendőr lőfegyvert használhat, a rendőrségi törvény tételesen felsorolja az 54. §-ban. A törvény szövege a tételes felsorolás előtt az 52. §-ban utal arra, hogy ,, a rendört a löfegyver használati jog - a jogos védelem és a végszükség esetein kivül - az e törvényben foglaltak szerint illeti meg".

A rendőrségi törvény szövegéből kiderül, hogy az 54. §-ban tételesen felsorolt eseteken túl jogos védelmi helyzetben és végszükségben is lehetösége van a rendőrnek a fegyverhasználatra. Miért ne illetné meg a rendőrt a jogos védelem, hiszen már az alaptörvény $\mathrm{V}$. cikkében is szerepel, vagyis alkotmányos alapjogként fogható fel, hogy ,,mindenkinek joga van a törvényben meghatározottak szerint a személye illetve tulajdona ellen intézett vagy ezeket közvetlenül fenyegetö jogtalan támadás elháritásához”.

\section{Jogos védelem során alkalmazott rendőri fegyverhasználat}

E jogintézményt a 2013. július 1-jén hatályba lépő, a büntető törvénykönyvről szóló 2012. évi C. törvény jelentősen megváltoztatta, leginkább az úgynevezett szituációs jogos védelem bevezetésével, és némileg változtatta az úgynevezett klasszikus jogos védelem szövegét is, de erre e tanulmány keretei között nem térek ki.

Az úgynevezett klasszikus jogos védelemnél előforduló rendőri fegyverhasználat:

22. § (1) Nem büntetendö az a cselekmény, amely a saját, illetve más vagy mások személye, javai vagy a közérdek ellen intézett, illetve ezeket közvetlenül fenyegetö jogtalan támadás elháritásához szükséges.

E tanulmány készítésekor az elmúlt öt év rendőri fegyverhasználatát (öszszesen tíz eset) vizsgáltam meg. Az összes esetnél klasszikus jogos védelmi helyzet is fennállt, illetve az összes esetnél az Rtv. egyes más pontjai alapján is jogszerünek minősítették a fegyverhasználatot. (Megjegyzem, a jogos vé- 
delmi helyzet és egyes a törvényben felsorolt szituációk között átfedések észlelhetők, de erről majd az egyes szituációk elemzésénél írok részletesebben.)

A gyakorlatban rendőri fegyverhasználati jogot keletkeztető klasszikus jogos védelmi szituációk a következők:

- ha a rendőrt intézkedés során vagy szolgálatellátása során váratlanul támadják meg;

- más személyt ér támadás, akinek a védelmében fellép a rendőr;

- a felsorolt támadások a rendőr vagy a megtámadott személy élete, testi épsége ellen irányulnak.

A korábbi Btk. alapján sok esetben hibás jogalkalmazói (ügyészi, bírói) gyakorlat alakult ki abban a tekintetben, ahogyan a jogos védelmi helyzetek megítélésénél az arányosságot és a szükségességet vizsgálták. A kialakult hibás gyakorlat bizonyos esetekben az volt, hogy külön-külön vizsgálták a szükségességet és arányosságot. Az arányosság problémájának vizsgálata bizonyos esetekben oda vezetett, hogy mérlegre helyezték: milyen sérülés okozására terjedt ki a támadó szándéka, és milyen sérülést okozott ténylegesen az elhárító cselekmény. Ha az elhárító cselekmény irányába billent a mérleg nyelve a sérülés foka tekintetében, akkor az elsőfokú itéletben túllépést állapítottak meg, míg végül a Legfelsőbb Bíróság a védekező javára döntött. ${ }^{7}$ Voltak olyan szélsőséges esetek is, ahol csupán a támadó és az elhárító eszközt vetették össze, és az elhárító eszköz élet kioltására való alkalmassága alapján állapították meg a túllépést, vagy a jogos védelem hiányát. ${ }^{8}$

A kialakult hibás gyakorlatot egyébként a jogirodalom számos esetben bírálta9 ${ }^{9}$ míg végül az új Btk. hatálybalépése után 4/2013. BJE határozatában a Kúria rendezte a kérdést, és kijelentette, hogy ,, a védekezö cselekmény jogszerüségének egyetlen kritériuma a szükségesség”.

7 Példa erre a BH 1996. 292. számú jogeset: „A jogos védelem esetében a szükségesség és az arányosság megítélésénél a jogtalanul támadó valóságos szándékára a megtámadott az objektív tények és a külső megjelenési formák alapján következtethet, ezért a támadó részéről az ölésre irányuló szándék közlése, majd a megtámadott nyakának megszorításával történő fojtogatása közben a támadónak a megölése nem értékelhető az elhárításhoz szükséges mérték túllépéseként, így a jogos védelem címén történő felmentés indokolt [Btk. 29. §, 166. § (1) bek., Be. 214. § (3) bek. c) pont]."

8 Jogos védelmi helyzet megállapításának téves mellözése olyan esetben, amikor a vádlott az ellene puszta kézzel intézett támadást eszköz (kés) használatával hárítja el. BH, 1990/367.

9 A teljesség igénye nélkül lásd Kónyáné Kutrucz Katalin: Szükséges-e az arányosság a jogos védelemhez? Magyar Jog, 1985/12., 875., 877. o., Blaskó Béla: A jogos védelem néhány elméleti és gyakorlati kérdése. Főiskolai Figyelő, 1992/2., 96. o.; Ujvári Ákos: A jogos védelem megitélésének elvi és gyakorlati kérdései. Doktori értekezés, 2008. 
Amint arra egy korábbi tanulmányomban is hivatkoztam, a gyakorlatban a szükségesség vizsgálata jogos védelmi helyzetben azt jelenti, hogy „elsösorban azt kell vizsgálni, hogy fennállt-e a jogtalan támadás ténye, amennyiben igen akkor a szükségesség már nem vitatható, a védekezö jogos védelmi helyzetben volt. Innentöl kezdve a túllépés szempontjából kell vizsgálni azt volt-e enyhébb védekezési módja a védekezönek, amennyiben igen, azt tudatosan tette-e félre avagy ijedtségböl, menthetö felindulásból. "'lo

Két alapkérdés szerint kell megkezdeni egy jogos védelmi helyzetben alkalmazott rendőri fegyverhasználat kivizsgálását:

- jogtalan támadás vagy azzal való közvetlen fenyegetés ténye fennállt-e;

- enyhébb védekezési mód kizárható volt-e.

A jogtalan támadás vagy azzal való közvetlen fenyegetés fennállásának megállapítása olyan ténykérdés, amelyet az intézkedő rendőr jelentéséből, a rendőr, a jelen lévő tanúk és az intézkedés alá vont személy meghallgatásával lehet tisztázni.

Felvetődik a kérdés: mi minősül jogtalan támadásnak, ami alapot adhat a jogos védelmi helyzet megállapításához?

A jogirodalom által kidolgozott meghatározások szerint a jogtalan támadás „egyfajta pozitiv kihatás, melyhez az ártás, illetve az ártással való fenyegetés képzetét füzzük" "II , olyan aktív magatartással valósítható meg $^{12}$, ami a létező állapot megváltoztatására irányuló erőszakos fellépés formájában jelentkezik. ${ }^{13}$ A bírói gyakorlat szerint jogos védelmi helyzet alapjául nemcsak aktív, hanem passzív emberi magatartás is szolgálhat, ,ha a passziv magatartás lényegében a leendö sértett(ek) részéröl a már elkövetett büncselekménynek további folytatását célozza, még akkor is jogtalan támadásnak minösül, ha az elhárítás pillanatában ez nem párosul aktív magatartással (vö. BH 1997.512)"'14.

Az aktív támadásokra lehet példa, ha az intézkedő rendőrt megtámadják intézkedés közben, vagy más személy ellen irányuló aktív támadással szemben - jogos védelemből - alkalmaz lőfegyvert a rendőr.

Passzív magatartások ellen alkalmazható fegyverhasználatra lehet példa, ha az elkövető a sértett nyakához kést szorítva tart fogva valakit, akit végül egy rendőri fegyverhasználat tesz ártalmatlanná.

\footnotetext{
10 Zsigmond Csaba: Az új jogos védelem jogalkalmazói problémái és kérdései. Belügyi Szemle, 2014/7-8. 11 Degré Lajos: Jogos védelem az anyagi büntetőjogban. Pestvidéki Ny., Vác, 1910, 277. o.

12 Földvári József: Magyar Büntetőjog Általános Rész. Osiris Kiadó, Budapest, 1997, 137. o. [Osiris tankönyvek]

13 Finkey Ferenc: A Magyar Büntetőjog Tankönyve. Grill, 1914, 207-208. o.

14 Nagy Ferenc: i. m. 191. o.
} 
A gyakorlatban a jogtalan támadások lehetnek a rendőr vagy más személy élete, testi épsége ellen irányuló közvetlen, intézett támadások, vagy azzal való közvetlen fenyegetések.

Az intézett támadások megállapítása a gyakorlatban nem okozhat különösebb nehézséget, hiszen egy személy elleni - testi sértés, emberölés, hivatalos személy elleni erőszak - már legalább kísérleti szakaszba jutott cselekményének elhárítására irányul a fegyverhasználat mint jogos védelem.

Az intézett támadásokon kívül a közvetlenül fenyegető cselekmények is alapot adhatnak a jogos védelmi helyzet megállapításához. Az elmúlt öt évben keletkezett tíz fegyverhasználati esetböl négyben közvetlenül fenyegető támadás elhárítására alkalmaztak a rendőrök fegyvert.

A felsorolt esetekben a támadás még nem volt intézett, azonban a jogtalan támadás ténye közvetlen fenyegetésként volt értékelhetö, így mindegyik esetben jogszerü volt a fegyverhasználat. A közvetlenül fenyegető támadás tényére mindegyik esetben utalt az, hogy az elkövető élet kioltására alkalmas eszközt (fegyver, fegyvernek látszó tárgy, szúróeszköz) tartott a kezében, és a támadást megelőző körülmények (például az elkövető közlései) utaltak arra, hogy azt használhatja. A közvetlenül fenyegető támadások elhárítására alkalmazott fegyverhasználati eseteknél a vizsgálat során a jogos védelem megállapításához támpontot nyújthat az a tény, ha a támadónál az imént említett, az élet kioltására alkalmas eszköz volt, amelynek alkalmazását a rendöri fegyverhasználat akadályozta meg.

A következő alapkérdés jogos védelmi fegyverhasználat esetén annak tisztázása, hogy enyhébb elhárítási mód - azaz enyhébb kényszerítő eszköz - alkalmazása kizárható volt-e az adott helyzetben. Ha egyértelmüen lett volna lehetőség enyhébb kényszerítő eszköz alkalmazására, ehelyett a rendőr mégis fegyvert használt, akkor a jogos védelmi helyzetben minőségbeli túllépés állapítható meg, és a fegyverhasználat nem tekinthető jogszerünek. A túllépés egyébként a fegyverhasználati alapelveknél kifejtett arányosságot is sérti.

Testi kényszer és bilincs alkalmazásának kizárását támaszthatja alá az a tény, ha a támadó egyértelmüen erőfölényben volt, és a rendőr ezekkel a kényszerítő eszközökkel nem tudta volna a támadást elhárítani. ${ }^{15}$

\footnotetext{
15 A rendőrség szolgálati szabályzatáról szóló 30/2011. (IX. 22.) BM rendelet 40. § szerint: „A megfogás, a leszorítás, az elvezetés vagy más, a rendőr által fizikai erőkifejtéssel alkalmazott, valamely cselekvésre vagy cselekvés abbahagyására irányuló kényszerítés (a továbbiakban: testi kényszer) akkor alkalmazható, ha a rendőri erőfölény vagy az intézkedés alá vont személy állapota, magatartása folytán a rendőri intézkedés eredményessége ezzel biztosítható."
} 
Kizárhatja továbbá az enyhébb kényszerítő eszköz alkalmazását az azonnali beavatkozás szükségessége, vagyis csak azonnali rendőri fegyverhasználattal akadályozható meg, hogy a jogtalan támadó életet oltson ki. A gyakorlatban erre a szituációra tipikus példa, ha a jogtalan támadó lőfegyverrel vagy más, az élet kioltására alkalmas eszközzel hajtja végre a támadást, vagy azzal közvetlenül fenyeget. Ilyen esetekben a fenyegetés súlyosságára, az eszköz veszélyességére tekintettel nem kerülhet sor más kényszerítő eszköz alkalmazására, hanem közvetlenül lőfegyver alkalmazható. Az általam vizsgált esetek közül csupán egy esetben volt lehetőség enyhébb kényszerítő eszköz alkalmazására. Az intézkedő rendőr testi kényszer és vegyi eszköz alkalmazásával próbálta a jogtalan támadást elhárítani, mivel azonban ez eredménytelen volt, ezért a legsúlyosabb kényszerítő eszközt kellett alkalmaznia.

\section{A szituációs jogos védelemnél alkalmazott rendőri fegyverhasználat}

Az új Btk. 2013. július 1-jétől vezette be ezt a jogintézményt. A szituációs jogos védelemmel a rendőr rendkívül bizonytalan helyzetbe került. Az új Btk. és a szituációs jogos védelem bevezetésével egyidejüleg nem igazították a megváltozott jogi környezethez a rendőri fegyverhasználatot.

A hatályos Btk. szerint:

(2) A jogtalan támadást úgy kell tekinteni, mintha az a védekezö életének kioltására is irányult volna, ha

a) azt személy ellen

aa) éjjel,

ab) fegyveresen,

ac) felfegyverkezve vagy

ad) csoportosan

követik el,

b) az a lakásba

ba) éjjel,

bb) fegyveresen,

bc) felfegyverkezve vagy

bd) csoportosan

történö jogtalan behatolás, vagy

c) az a lakáshoz tartozó bekerített helyre fegyveresen történö jogtalan behatolás. 
Szituációs jogos védelmi helyzetben a rendőrt vagy más személyt az a) pontban meghatározott szituációkban éri személy elleni jogtalan támadás. A b) pont esetén a jogtalan behatolás során tanúsított támadás minősül élet elleni támadásnak a felsorolt szituációkban, illetve a c) pont esetén a lakáshoz tartozó bekerített helyre fegyveresen való behatolás során elkövetett jogtalan támadás tekinthető élet elleni támadásnak. Ezekben az Rtv. alapján elvileg fegyverhasználat illeti meg a rendőrt, azonban számos gyakorlati kérdés vetődik fel.

Az a) szerinti szituációknál sem a Btk. szövege, sem más jogszabály nem határozza meg vagy sorolja fel, mely magatartások minősülhetnek olyan személy elleni jogtalan támadásnak, amelyek a szituációs jogos védelmi helyzetet megalapozhatják. Jogalkalmazói probléma, hogy ezek azonosak-e a Btk. (Értelmező rendelkezések 459. § 26. pont) szerinti személy elleni erőszakos büncselekményekkel.

A Btk. 459. § i) pont szerint például a hivatalos személy elleni erőszak ${ }^{16}$ is személy elleni büncselekménynek minősül. Abban az esetben, ha ezt az értelmezést követjük, minden olyan esetben fennáll a rendör fegyverhasználati joga, ha az intézkedő rendőr sérelmére a felsorolt szituációkban (például éjjel, vagy csoportosan) hivatalos személy elleni eröszakot követnek el.

Fegyverhasználat vizsgálatakor feltétlenül szükséges a hivatkozott tényállás elkövetési magatartásainak gyakorlati értelmezése, és ezek vizsgálata is okozhat problémás helyzetet.

\section{A hivatalos személy elleni erőszak mint személy elleni cselekmény}

Jogszerü eljárásában erőszakkal vagy fenyegetéssel akadályoz elkövetési alakzat: „Az akadályozás olyan tevékenység amelynek következtében a hivatalos személy nem tudja tovább folytatni a hivatalos eljárását. Az akadályozás megnyilvánulhat a mozgás, továbbjutás, valaminek a megléte korlátozásában, a korlátozás idötartama közömbös. Az akadályozás erössége sem befolyásolja a cselekmény minösitését: megvalósul a cselekmény olyan eset-

\footnotetext{
16 Btk. 310. § (1) „Aki hivatalos vagy külföldi hivatalos személyt

a) jogszerü eljárásában erőszakkal vagy fenyegetéssel akadályoz,

b) jogszerü eljárásában erőszakkal vagy fenyegetéssel intézkedésre kényszerít, vagy

c) eljárása alatt, illetve emiatt bántalmaz,

bűntett miatt egy évtől öt évig terjedő szabadságvesztéssel büntetendő.”
} 
ben is, amikor az akadályozás a hivatalos személy eröteljesebb, határozottabb fellépésével elháritható lett volna." ${ }^{17}$

A joggyakorlat által megkívánt fontos feltétel, hogy az akadályozó cselekmény csak aktív magatartással valósítható meg, tehát a rendőri felszólításra valaminek a meg nem tétele nem valósítja meg a cselekményt. Az intézkedő rendőr karjának megragadása, elhúzása, eltolása már megvalósíthatja az erőszakkal akadályozás elkövetési magatartását. ${ }^{18}$ Fontos gyakorlati feltétel, hogy a rendőr akadályozása erőszakkal vagy fenyegetéssel történjen. ${ }^{19}$

A Legfelsőbb Bíróság kifejtette: „Az erőszak fogalmát a törvény nem határozza meg. A birói gyakorlat értelmében az eröszak fizikai erőkifejtéssel történö közvetlen vagy dolog által közvetitett személy ellen irányuló tudatos meghatározó jellegü ráhatás, amelyet a konkrét eset összes körülményének figyelembevételével kell vizsgálni és megitélni."

A BH 2005. 339. számú jogesetnél az intézkedés alá vont személy anélkül, hogy a rendőr felé fordult volna, a dzsekijét dobta az intézkedő rendör arcába azért, hogy elfuthasson, és kivonja magát az intézkedés alól. A Legfelsőbb Bíróság nem állapította meg az akadályozással elkövetett hivatalos személy elleni erőszakot, mivel álláspontja szerint , a terhelt magatartása nem volt támadó jellegü, a sértettet veszélyhelyzetbe nem hozta. A terhelt által a dzseki eldobásakor alkalmazott egyetlen mechanizmusú fizikai erökifejtés intenzitása, az erökifejtést közvetítő dolog súlya, jellege és annak alkalmazási módja, a sértettre gyakorolt nem meghatározó, jelentéktelen hatása nem érte el az eröszaknak azt a fokát, amelyet a birói gyakorlat az eröszakkal elkövetéshez megkiván. Viszont kétségtelenül alkalmas volt arra, hogy a sértett figyelmét elvonja és rövid időre jogszerü intézkedésében akadályozza. A terhelt szándéka is erre irányult, célja az volt, hogy az eljárás alól kivonja magát, hogy elmeneküléséhez idöt nyerjen."

A jogeset is mutatja, hogy a gyakorlatban mind a közterületi intézkedés során, mind a parancsnoki kivizsgáláskor nehéz lesz mérlegelni, milyen szin-

\footnotetext{
17 Erdősy Emil - Földvári József - Tóth Mihály: Magyar büntetőjog Különös Rész. Rejtjel Kiadó, Budapest, 1997, 224. o.

18 Lásd a BH 1999. 437. számú ügy. A Legfelsőbb Bíróság kifejtette: A hivatalos személy elleni erőszak büntette megvalósul, ha az elkövető - akár közvetlen, akár közvetett formában - aktívan ellenszegülve, testi erőkifejtéssel gátolja, nehezíti, vagyis akadályozza a hivatalos személyt a jogszerü intézkedés megtételében [Btk. 229. § (1) bek.]. Ennél az esetnél az intézkedés alá vont személy megragadta az intézkedő rendőr ruháját, majd ellökte. A Legfelsőbb Bíróság szerint ez a magatartás ,az erőszakkal akadályozás tényállási fordulatot kimeríti”.

19 „Hivatalos személy elleni erőszak büntette - a hivatalos személy jogszerü eljárásában való akadályozásával - akkor valósul meg, ha az akadályozás erőszakkal vagy fenyegetéssel történik [1978. évi IV. törvény 229. § (1) bek. I. ford.].” BH, 2005/339.
} 
tü erőszak alkalmas arra, hogy akadályozással elkövetett hivatalos személy elleni erőszak megállapítható legyen, és a szituációk fennállása esetén akár a legsúlyosabb kényszerítő eszköz alkalmazásának lehetőségét is megnyissa. Erőszakkal akadályozással elkövetett hivatalos személy elleni erőszak fennállását állapították meg olyan esetben, amikor az intézkedő hivatalos személy (ennél a jogesetnél halőr) az intézkedés alá vont személy gépkocsival való helyszínről távozásának megakadályozása céljából a gépkocsi csomagtartójára ugrott, és az intézkedés alá vont így indult el. ${ }^{20}$

Jogszerủ eljárásában erőszakkal vagy fenyegetéssel intézkedésre kényszerítés: „A passzív hivatalos személy az alaki szabályoknak megfelelö olyan aktiv tevékenységet fejt ki, intézkedik, amelynek anyagi jogi szabályai egyébként nem állnak fenn. A hivatalos személy olyan jogilag értékelt tevékenységet kénytelen kifejteni, amely nem az ö, hanem az elkövetö akaratának felel meg. $E$ körben is érvényes, hogy az engedelmesség megtagadása, a passziv ellenállás nem intézkedésre kényszerités. "21

„Nem minösithetö intézkedésre kényszeritésnek az az eset, amikor az ajtó ki nem nyitása miatt arra kényszerül a hivatalos személy, hogy azt felnyissa vagy betörje." 22

Az eljárása alatt, illetve emiatt bántalmaz elkövetési alakzat - a leggyakrabban előforduló formája a hivatalos személy elleni erőszaknak, ha az intézkedő rendőrt eljárása alatt bántalmazzák. A bántalmazás a kialakult jogi gyakorlat szerint más testének szándékos jogellenes és célzatos érintése. A jogtudomány egyes müvelői ,, a célzatos érintés helyett eröszakos jellegü behatást kivánnak meg"'23. A kialakult bírói gyakorlat szerint nem szükséges, hogy a bántalmazás következtében testi sérülés is keletkezzen. ${ }^{24}$

Gyakorlatilag az intézkedő rendőr meglökése, meglegyintése, de tárgyak szándékosan a rendőr felé dobása ${ }^{25}$, vagy akár a testére mért igen csekély erejü ütés is alkalmas lehet a hivatalos személy elleni erőszak megállapítására. Ha ilyen esetekre a szituációs jogos védelemnél megfogalmazott valamely feltétel fennállásakor kerül sor, ismét felvetődik a rendőri fegyverhasználat problémája.

20 Lásd BH, 2004/129

21 Belovics Ervin - Molnár - Sinku Pál: Büntetőjog Különös Rész. HVG ORAC Kiadó, Budapest, 2002, 263. o.

22 Erdősy Emil - Földvári József - Tóth Mihály: i. m. 224. o.

23 Uo. 216. o.

24 Lásd Blaskó Béla: A hivatalos személy elleni erőszak elméleti kérdései. Belügyi Szemle, 1990/6., 18. o.

25 A már hivatkozott BH, 2005/339. számú ügyben a dzsekijét az intézkedő rendőr arcába dobó személy cselekményét - az eset összes körülményénbek figyelembevételével - a Legfelsőbb Bíróság nem értékelte támadó jellegünek. 
Még nagyobb nehézséget okozhatnak a gyakorlatban a szituációs jogos védelmi helyzeteknél a Btk.-ban megfogalmazott közvetlenül fenyegetö támadások esetei.

Valamely körülmény fennállása esetén a rendör felé irányított fenyegető kézmozdulat elvben megalapozhatja a rendőri fegyverhasználatot is.

\section{A büncselekmény elkövetési ideje, motívuma}

A hivatalos személy elleni erőszak büntettének vizsgálatakor feltétlenül tisztázni kell az elkövetési időt, illetve az eljárása miatt elkövetési mód esetén a cselekmény motívumát. Tisztázni kell, hogy a rendőr elleni támadásra a rendör jogszerü eljárásában, jogszerü eljárása alatt vagy amiatt került-e sor. Ha nem a hivatkozott időtartamban, vagy nem a hivatkozott ok miatt (eljárása miatt), a hivatalos személy elleni erőszak nem állapítható meg. Itt jegyezném meg, ha nem jogszerü eljárás során vagy jogszerü eljárás miatt ellene irányuló támadás elháritása során használ a rendör fegyvert, a fegyverhasználat nem értékelhetö rendőri fegyverhasználatként, és nem az erre vonatkozó szabályok alapján kell eljárni.

\section{Jogszerü eljárás}

Jogszerü eljárásban vesz részt a rendőr, amikor valamelyik, a rendőrségi törvényben foglalt rendőri intézkedést hajtja végre ${ }^{26}$, vagy más jellegű szolgálati feladatot lát el: például személyőrzés, átkísérés, vagy akár bünügyi nyomozóként a büntetőeljárási törvényben foglalt valamely nyomozati cselekmény (például kihallgatás, házkutatás, felismerésre bemutatás stb.).

Kijelenthető, hogy nem minden esetben csupán a konkrét rendőri intézkedések vagy nyomozati cselekmények végrehajtása jogszerü eljárás. Minden szolgálatban lévő rendőr jogszerüen jár el anélkül, hogy konkrét intézkedést vagy nyomozati cselekményt hajtana éppen végre. A Legfelsőbb Bíróság egyik eseti döntésében leszögezte: „A hivatalos személyt nemcsak a szó szoros értelmében vett közhatalmi tevékenységének a kifejtése során illeti meg a fokozott büntetöjogi védelem, hanem általában a szolgálata (munkaideje) alatt, amikor felkészül, illetve készenlétben áll az esetleges intézkedésre, és az

26 Lásd az Rtv. V. fejezetében felsorolt intézkedéseket. 
ellene irányuló - eröszakkal vagy fenyegetéssel történö - ráhatás akadályozza a tervezett vagy szükségessé váló intézkedés megtételét (Btk. 229. §)." ${ }^{27}$

A gyakorlatban a járőrkocsiban ülő járörök ellen intézett váratlan támadás vagy az örszolgálatot ellátó rendőr leütése is hivatalos személy elleni erőszaknak minősül, holott konkrét rendőri intézkedést - konkrét közhatalmi tevékenységet - nem végeznek. Kijelenthető, hogy a rendőrt védi a büntetö törvénykönyv akkor is, ha a munkaideje alatt szolgálatban van. Érdekes gyakorlati kérdésként vetődik fel, hogy a szolgálatban lévő, de munkaközi szünetet töltő rendőr ellen irányuló támadás is hivatalos személy elleni erőszaknak minősül-e. Állásontom szerint az idézett BH alapján igen. Konkrét gyakorlati példaként fordulhat elö, ha a járör tevékenységet ellátó rendörök munkaközi szünetben egyenruhában térnek be ebédelni, amikor is támadás éri öket.

Gyakorlati kérdésként vetődhet fel az intézkedés jogszerüségének kérdése. A jogszerütlen intézkedés is élvezhet büntetőjogi védelmet. ${ }^{28}$ A probléma megítélése szempontjából különbséget kell tenni az eljárás anyagi és eljárásjogi (alaki) jogszerütlensége között. ${ }^{29}$ Anyagi jogi szempontból jogszerütlen intézkedés esetén a rendőr elleni támadás szintén hivatalos személy elleni erőszaknak minősülhet. Ugyanis az ilyen jellegü intézkedések ellen az Rtv. alapján utólag panaszt nyújthat be az intézkedés alá vont személy, az intézkedés során nem támadhatja meg a rendőrt. Például valakinek hanyagságból nem vonják vissza a körözését, és ezért elöállítják. Az előállítás során köteles magát a rendőri intézkedésnek alávetni, holott anyagi jogi szempontból nem jogszerủ az intézkedés.

Ellenben az eljárásjogilag kirívóan jogtalan intézkedések nem részesülnek büntetőjogi védelemben. Például ittasan intézkedik a rendőr, ennek során az intézkedés alá vont személy erőszakkal próbálja a rendőrt magától távol tartani. A kirívóan jogellenes cselekmények erőszakkal és fenyegetéssel is akadályozhatók. Az ilyen kirívóan jogtalan intézkedés során alkalmazott fegyverhasználat nem minősíthető jogszerünek.

A Btk. nemcsak a rendőr hivatalos eljárása alatt elkövetett hivatalos személy elleni eröszakot rendeli büntetni, hanem azokat a cselekményeket is, amelyekre a rendőr jogszerü eljárása miatt kerül sor. Konkrét gyakorlati példája ennek, ha a szolgálatban nem lévő rendőrt utólag valamely szolgálati feladatával kapcsolatban bosszúból bántalmazzák.

27 Lásd BH, 1995/620.

28 Rtv. 19. §. „A rendőri intézkedés során annak jogszerütlensége nem vonható kétségbe, kivéve, ha a jogszerütlenség mérlegelés nélkül, kétséget kizáróan megállapítható."

29 Erdősy Emil - Földvári József - Tóth Mihály: i. m. 226. o. 


\section{A garázdaság mint a személy elleni büncselekmény problémája}

Ugyancsak jogalkalmazói kérdésként vetődik fel, ha a jogos védelemnél megfogalmazott személy elleni erőszak fogalmának értelmezésekor a Btk. 459. § Értelmezö rendelkezéseket tekintjük alapnak, az ott található felsorolásból a garázdaság tényállása kimaradt. Pedig tipikus eset lehet például, hogy a rendőrt éjszakai szolgálat ellátása során egy garázdasághoz irányítják. A kiérkező rendőrt egy éppen zajló verekedés fogadja, amelyben az egyik fél bántalmaz egy másikat. A helyzet adott, mégis felvetődik a kérdés, hogy a garázdaság a szituációs jogos védelmi helyzetet megalapozó személy elleni cselekménynek minősül-e, tehát alkalmazhat-e a rendőr löfegyvert a támadás elhárítására, a garázda cselekmény megszakítására.

\section{Az egyes szituációk értelmezési problémái}

A másik jogalkalmazói probléma a Btk. szövegben szereplö éjjel fogalmának az értelmezése. Mikortól számíthatjuk az éjjelt? A Kúria jogegységi határozata a korábbi büntetőjog-alkalmazás gyakorlatára hivatkozik: ,,Az éjjel fogalmára sem az új, sem a korábbi Btk. nem ad meghatározást, azonban a magánlaksértés itélkezési gyakorlata ennek a napszaknak az értelmezését kialakitotta, országosan egységesen kezeli, és nincs olyan ok, amely miatt attól eltérni kellene, tehát az a jogos védelem új rendelkezéseinél is változatlanul irányadó. "'30

A hivatkozott ítélkezési gyakorlatot a korábbi Btk. kommentárja alapozta meg. A kommentár a magánlaksértésnél így definiálta az éjjel fogalmát: , A gyakorlat általában a 23 óra és 05 óra közötti elkövetést tekinti éjjeli idöpontnak."

Gyakorlati kérdés, hogy megállapítható-e a szituációs jogos védelem, és a jogszerü fegyverhasználat abban az esetben, ha a rendör éjfélkor, Budapest belvárosában egy jól kivilágított, forgalmas helyen hárít el egy jogtalan támadást, viszont nem állapítható meg, ha télen 19 óra körüli időben - amikor már sötét van -, egy kihalt külvárosi részen kell fegyvert használnia ellene vagy más személy ellen intézett garázda jellegủ támadás elhárítására.

Mit tekintsen irányadónak az intézkedő rendőr, vagy a fegyverhasználat után a rendőr parancsnoka? Erre sem a hatályos jogszabályok, sem a kialakult joggyakorlat nem ad választ.

30 Részlet a Kúria 4/2013. BJE határozatából. 
A szituációs jogos védelem a) pontban felsorolt további - fegyveresen, felfegyverkezve, csoportosan - fogalmakat a jogalkotó egyértelmüen megfogalmazza a Btk. 459. §-ában, ezeknek a fennállása esetén nem vetődhet fel jogértelmezési probléma. A fegyveresen, felfegyverkezve elkövetett támadások esetén egyébként az Rtv. 54. § (1) bekezdésének d) és i) pontjai alapján is megállapítható a fegyverhasználat jogossága.

Gyakori eset, hogy éjjel intézkednek rendörök. Hogyan értékelhetö, ha valaki egy éjszakai rendőri intézkedés során hirtelen mozdulattal a zsebéhez kap, vagy más hirtelen, fenyegető jellegü mozdulatot tesz a rendőr felé, és a rendőr ezt közvetlen fenyegetésként értékelve fegyvert használ? A szituációs jogos védelem feltételei adottak: éjjel, személy elleni irányuló közvetlenül fenyegető támadásként értékelhető, mely esetben a szituációs jogos védelem szabályai szerint a támadás élet ellen irányuló közvetlen fenyegetésnek tekinthető. Az Rtv. felhatalmazást ad a fegyverhasználatra.

Éjszakai rendőri intézkedések során a vázolt szituáció gyakran előfordul, ezért egyáltalán nem kizárható, hogy a rendörök ilyen helyzetben fegyvert használnak. Hogyan értékelje a parancsnok? Jogszerünek a szituációs jogos védelem alapján, vagy jogszerütlennek. Akármelyiket választja, teljesen bizonytalan helyzet alakulhat ki, mind a rendőrök, mind az állampolgárok oldaláról. Az értékeléskor nyilvánvalóan figyelemmel kell lenni az Rtv. 15. §-ában foglalt arányosság követelményére is. ${ }^{31} \mathrm{Az}$ arányosság alapján való mérlegelés viszont ellentmond a bevezetett új jogintézmény jogpolitikai indokainak, hiszen pontosan azért vezették be a szituációs jogos védelem jogintézményét, hogy a szituációk fennállása esetén mérlegelés nélkül elismerje a támadás elhárításának jogosságát, vagyis a jogalkotó által veszélyesnek ítélt helyzetekben zajló támadások minden esetben korlátozás nélkül elháríthatók legyene ${ }^{32}$, és az elhárító cselekmény után ne legyen mérlegelés, ne induljon büntetőeljárás. ${ }^{33}$

\footnotetext{
31 Rtv. 15. § (2) „Több lehetséges és alkalmas rendőri intézkedés, illetőleg kényszerítő eszköz közül azt kell választani, amely az eredményesség biztosítása mellett az intézkedéssel érintettre a legkisebb korlátozással, sérüléssel vagy károkozással jár.”

32 Az új Btk. miniszteri indoklása szerint: ,a jogtalan támadás körülményei megteremtik a lehetőséget a védekezés szükségességének túllépésére”. Ezt kiegészítve Tóth Mihály megjegyzi: „,valójában a rendelkezés nem túllépésre ad felhatalmazást, hanem a szükségesség mértékének felülvizsgálata alól ad felmentést".

33 „Az új törvény a jogos védelmet, a büntethetőséget kizáró vagy korlátozó okok között objektív büntethetőségi akadályként kezeli, amikor a jogos védelem során megvalósított cselekményt »nem büntetendőnek « tekinti... A büncselekmény hiánya olyan büntetőeljárási akadály, amelynek hivatalból történő észlelése nemcsak a már megindított büntetőeljárás megszüntetését, vagy bírósági szakban felmentő ítélet hozatalát kell eredményezze, de elejét veheti annak is, hogy a védekező egyáltalán büntetőeljárás hatálya alá kerüljön."
} 
A Btk. 22. § b) pontban felsorolt szituációk fennállásakor, vagyis amikor a lakásba történő jogtalan behatolás

- éjjel;

- fegyveresen;

- felfegyverkezve;

- vagy csoportosan történik, ezekben az esetekben szintén alkalmazhat a rendőr fegyvert.

A Kúria 4/2013. BJE határozata kifejti: „, A lakásba történő jogtalan behatolás, maga a jogtalan támadás, mely azonban kizárólag aktív magatartással valósitható meg. Nem alapozza meg ezt a jogos védelmi helyzetet, ha a lakásba jogszerüen bejutó személy utóbb a lakást felszólitás ellenére nem hajlandó elhagyni."

Az idézett törvényi rendelkezés az Rtv. 39. § (1) bekezdésének b) pontjában megfogalmazott helyzetben ${ }^{34}$ vetheti fel a rendőri fegyverhasználat lehetőségét, vagyis amikor valaki úgy hatol be másnak a lakásába, hogy azzal bủncselekményt valósít meg, és a rendőr ilyen szituációban intézkedik (lakásbetörés vagy magánlaksértés elkövetése).

A Btk. szövege és a Kúria idézett jogegységi határozata alapján kijelenthetö, hogy gyakorlatilag egy már folyamatban lévő betörés elkövetőjével szemben alkalmazható lőfegyver.

A gyakorlati problémák további taglalása előtt először is a Btk. által használt fogalmak kapcsán felvetődő értelmezési problémákra érdemes kitérni.

A szituációs jogos védelemnél a lakás fogalmát a Btk. nem határozza meg. Felvetődik a kérdés, hogy a Btk. által használt lakás fogalma azonos lehet-e a rendőrségi törvény Értelmezö rendelkezésben megfogalmazott magánlakás fogalmával egy rendőri intézkedés szempontjából.

Az Rtv. szerint magánlakás , a lakás (üdülö, nyaraló vagy a lakás céljára használt egyéb helyiség, létesitmény, tárgy), az ahhoz tartozó nem lakás céljára szolgáló helyiség, létesitmény, bekeritett terület”. A büntetőjogi jogirodalom szerinti lakásfogalom: „Lakás: minden olyan zárt hely, amely rendeltetésszerüen emberek tartózkodási helyéül és rendszeres szállásául szolgál. A definició fogalmi elemei konjuktivak, vagyis bármelyik feltétel hiánya esetén büntetöjogi értelemben lakásról nem lehet szó. A rendeltetésszerüségnek determináló jelentősége van, mert pl. az istálló abban az esetben sem minösül

$34 \mathrm{Az}$ Rtv. 39. § b) pontja szerint a rendör magánlakásban intézkedik: „,büncselekmény elkövetésének megakadályozása, megszakítása vagy büntetőeljárás terheltjének elfogása és előállítása céljából”. 
lakásnak - épp az eltérö rendeltetése miatt - ha alkalomszerüen, avagy nagy gyakorisággal éjjeli szálláshelyként szolgál. ",35

A gyakorlatban értelmezhető úgy a törvény, hogy például egy éjjeli lakásbetörés elkövetőjével szemben a szituációs jogos védelem alapján megilleti a fegyverhasználat a rendőrt. Felvetődik a kérdés: ha egy üzletben tartózkodnak betörők éjjel, a rendőrt nem illeti meg a fegyverhasználat?

Gyakran előfordul, hogy a rendőröket olyan helyzethez irányítják, ahol bérlö-tulajdonos közötti jogvita alakult ki egy lakásban. Például ha a lakás tulajdonosa nem a Ptk.-ban, illetve a bérleti szerződésben meghatározott módon gyakorolja a jogait, és ezzel szükségtelenül háborítja a bérlöt a lakás használatában, és erre éjjel kerül sor, a Btk.-ban megfogalmazott szituációk fennállnak (éjjel, magánlakásba való jogtalan behatolással követik el a büncselekményt). A Btk. és az Rtv. értelmezése alapján a szituáció rendőri fegyverhasználatot is megalapozhat. Az ilyen szituációknál utólag az eset többnapos elemzésével is rendkívül bonyolult eldönteni, hogy a lakás tulajdonosa jogosan vagy jogtalanul hatolt be erőszakkal a saját tulajdonát képező, de a bérlő által birtokolt lakásba. A helyszínen intézkedő rendőröknek a pillanat törtrésze alatt kell dönteniük.

A Btk. a szituációs jogos védelemnél a lakáshoz tartozó bekeritett helyre fegyveresen történö jogtalan behatolás esetét is élet elleni támadásnak tekinti, tehát ilyen helyzetekben is felvetődik a fegyverhasználat.

Már vázoltam a lakás fogalmi meghatározásait. Gyakorlatilag az előbbiekben felrajzolt lakásfogalmat fedő helyiségekhez tartozó bekerített helyekre való fegyveres behatolás élet elleni támadásnak minősül. Ha valaki kertbe fegyveresen hatol be, a Btk. alapján élet elleni támadást követ el, vagyis ez a szituáció is fegyverhasználatot alapozhat. Hozzáfüzöm, az Rtv. más rendelkezései alapján [Rtv. 54. § (1) bekezdés d) és i) pontja] is felvetődik a fegyverhasználat.

\section{Rendőri fegyverhasználat végszükségben}

Az Rtv. (52. §), illetve a hatályos Btk. alapján a rendőri fegyverhasználatra végszükségben is sor kerülhet. A végszükséget a büntető törvénykönyv a következők szerint szabályozza:

35 Belovics Ervin - Molnár - Sinku Pál: i. m. 146-147. o. 
„23. § (1) Nem büntetendö annak a cselekménye, aki saját, illetve más személyét vagy javait közvetlen és másként el nem háritható veszélyböl menti, vagy a közérdek védelme érdekében igy jár el, feltéve, hogy a cselekmény nem okoz nagyobb sérelmet, mint amelynek elháritására törekedett.

(2) Nem büntethetö, aki azért okoz nagyobb sérelmet, mint amelynek elháritására törekedett, mert ijedtségböl vagy menthetö felindulásból nem ismeri fel a sérelem nagyságát.

(3) Nem állapitható meg végszükség annak javára, akinek a veszély elöidézése felróható, vagy akinek a veszély vállalása foglalkozásánál fogva kötelessége."

A végszükség olyan veszélyhelyzet, ahol a veszélyforrás véletlenül keletkezett, vagy más személy által teremtett, és valaki a végszükségi helyzetben lévő személy mentése érdekében vagy más személy érdekében valamilyen büncselekményt követ el.

Ha rendőri fegyverhasználat szemszögéből nézzük, a Btk. látszólag nem teszi lehetővé a rendőr számára végszükségi helyzetben a fegyverhasználatot, hiszen a (3) bekezdés szerinti rendelkezés a rendőrre is vonatkozik, mivel a rendőrnek a veszély vállalása foglalkozási kötelessége. Az Rtv. és a Btk. ellentmondásosnak tủnik, az ellentmondást csak a jogirodalom segítségül hívásával oldhatjuk fel.

Szikinger István álláspontja szerint a rendőrnek csak a saját érdekében alkalmazott lőfegyver használata nem lehet alapja a végszükség megállapításának, más érdekében történt lőfegyverhasználat esetén viszont megengedhetőnek tartja. ${ }^{36}$ Ezt az álláspontot erősíti az Alkotmánybíróság 9/2004. (III. 30.) határozatának indokolásában kifejtett álláspontja is. ${ }^{37}$

A gyakorlatban az Rtv. és a Btk. által megfogalmazott arányosságot ${ }^{38}$ is figyelembe véve más érdekében is csak olyan veszélyhelyzetekben képzelhető el a rendőri fegyverhasználat, ha a mentett személy vagy személyek életének megmentése, vagyis életveszély elhárítása érdekében van szükség rá, hiszen a rendőri fegyverhasználat élet ellen irányuló kényszerítő eszköz. Ebből következően csupán vagyoni javak végszükségi helyzetben való megvédése érdekében nem indokolt a fegyverhasználat.

36 Szikinger István: Rendőrség a demokratikus jogállamban. Sík Kiadó Kft., Budapest, 1998, 144. o.

$37, \ldots$ a rendőri élethivatás részét képezi a veszélyhelyzetek vállalása, amelynek során saját élete védelme érdekében a végszüségre nem hivatkozhat".

38 A Btk. szerint akkor hivatkozhat valaki végszükségre, ha ,a cselekmény nem okoz nagyobb sérelmet mint aminek elhárítására törekedett”, illetve az Rtv. generális szabálya szerint „A rendőri intézkedés nem okozhat olyan hátrányt, amely nyilvánvalóan nem áll arányban az intézkedés törvényes céljával”. 
A gyakorlatban legvalószínübb, hogy fegyverhasználatra végszükségi helyzetben akkor kerülhet sor, ha katasztrófahelyzetben (tüz, árvíz) a mentési folyamatokat akadályozó személyt kell ártalmatlanná tenni. Előfordulhat olyan helyzetben is, ha valakit életveszélyes állapotban kell sürgősen kórházba szállítani, amit valaki szándékosan akadályoz.

Összességében tehát a gyakorlatban végszükségi helyzetben alkalmazott rendőri fegyverhasználat parancsnoki vizsgálatakor a jogszerüség szempontjából vizsgálandó, hogy a rendőr egyrészt más személy másrészt életének megmentése céljából, a kialakult konkrét életveszély elhárítása céljából alkalmazott-e lőfegyvert. Jogszerüség szempontjából mindkét feltételnek fenn kell állnia.

\section{IRODALOM}

Belovics Ervin - Molnár Gábor Miklós - Sinku Pál: Büntetőjog Különös Rész. HVG ORAC Kiadó, Budapest, 2002

Blaskó Béla: A hivatalos személy elleni erőszak elméleti kérdései. Belügyi Szemle, 1990/6.

Buzás Gábor: Közigazgatás - rendészet - rendöri intézkedés. PhD-értekezés. Pécsi Tudományegyetem Állam- és Jogtudományi Kar Doktori Iskola, Pécs, 2010

Degré Lajos: Jogos védelem az anyagi büntetőjogban. Pestvidéki Ny., Vác, 1910

Erdősy Emil - Földvári József - Tóth Mihály: Magyar büntetőjog Különös Rész. Rejtjel Kiadó, Budapest, 1997

Finkey Ferenc: A Magyar Büntetőjog Tankönyve. Grill, 1914

Földvári József: Magyar Büntetőjog Általános Rész. Osiris Kiadó, Budapest, 1997 [Osiris tankönyvek]

Nagy Ferenc: A magyar büntetőjog általános része. Korona Kiadó, Budapest, 2001

Nagy-Juhák István: A rendőr fegyverhasználati joga. BM Kiadó, Budapest, 1997

Szikinger István: Rendőrség a demokratikus jogállamban. Sík Kiadó Kft., Budapest, 1998

Zsigmond Csaba: Az új jogos védelem jogalkalmazói problémái és kérdései. Belügyi Szemle, 2014/7-8.

Korábban hatályos jogszabályok

A közbiztonság szervezéséről szóló 1881. évi III. törvénycikk

A magyar királyi rendőrség fegyverhasználati jogáról szóló 1932. évi XIII. törvénycikk

1958. évi 22. tvr.

1963. évi 22. tvr.

22/1958. BM parancs

A rendőrség szolgálati szabályzatáról szóló 3/1995. (III. 1.) BM rendelet 
A rendőrség szolgálati szabályzatáról szóló 62/2007. (XII. 23.) IRM rendelet A büntető törvénykönyvről szóló 1978. évi IV. törvény

\section{Hatályos jogszabályok}

Magyarország Alaptörvénye

A rendőrségről szóló 1994. évi XXXIV. törvény

A büntető törvénykönyvröl szóló 2012. évi C. törvény

A fegyveres szervek hivatásos állományú tagjainak szolgálati viszonyáról szóló 1996. évi XLIII. törvény

A rendőrség szolgálati szabályzatáról szóló 30/2011. (IX. 22.) BM rendelet 3/2004. (III. 30.) AB határozat

4/2013. BJE határozat

BH, 1990/367.

BH, 1996/292.

BH, 1997/437.

BH, 2003/227.

BH, 2004/129.

BH, 2005/339.

EBH, 2007/1583. 